\title{
Technical Efficiency of Agriculture in Ghana: A Time Series Stochastic Frontier Estimation Approach
}

\author{
Justice G. Djokoto \\ Lecturer, Department of Agribusiness \\ Central Business School, Central University College \\ P. O. Box DS 2310, Dansoman, Accra, Ghana \\ Tel: 233-28-503-7399_E-mail: dgameli2002@gmail.com
}

Received: June 23, 2011

Accepted: July 8, $2011 \quad$ Online Published: December 1, 2011

doi:10.5539/jas.v4n1p154

URL: http://dx.doi.org/10.5539/jas.v4n1p154

\begin{abstract}
A Cobb-Douglas production was fitted to time series data, 1961 to 2010 using stochastic frontier methodology. All factors of production possessed the a priori signs except land and seeds, whilst all except seeds variable were significant at $1 \%$ level. All the capital variables were output inelastic. Labour was elastic to output; with elasticity of 1.28. The sum of the elasticities equalled 1.74, indicative of increasing returns to Ghana's Agriculture over the period. The estimates of technical efficiency had a mean of $82 \%$ with a minimum of $59 \%$ and maximum of $96 \%$. Efforts remain to make up for the $18 \%$ inefficiency using the current technology. With a negative relationship between land and Agricultural output, coupled with the increasing population and increasing need for non-agricultural land uses, the need to adopt land productivity enhancing practices is necessary.
\end{abstract}

Keywords: Stochastic frontier analysis, Technical efficiency, Agriculture, Time series, Ghana

\section{Introduction}

Agriculture is the backbone of the Ghanaian economy, employs more than $60 \%$ of the labour force, and is predominantly rural. It also contributes significantly to gross domestic product (GDP) and foreign exchange earnings. For example, in 2006 the sector contributed $39.9 \%$ to GDP and $41.1 \%$ of foreign exchange was derived from traditional and non-traditional crops (ISSER, 2007). The major staple crops produced in Ghana include cereals (mainly rice and maize) and starchy staples such as yams, cassava and plantain. Crop production in Ghana is for three main reasons: food production for consumption, raw materials for industry and production for export. Animal production at the household level comprises poultry and small ruminants. Commercial productions of animals are mainly in poultry. Thus, among the various economic sectors of the Ghanaian economy agriculture is expected to lead economic growth in much of the country. According to Bogetic et al. (2007) and Coulombe \& Wodon, (2007), the poverty rate in Ghana fell from 51.7\% in 1991-1992 to $39.5 \%$ in 1998-1999 and 28.5\% in 2005-2006. This makes Ghana one of Sub-Saharan Africa's significant success stories in terms of growth and poverty reduction over the past 15 years. Real GDP has increased more than 4 percent per year since 1980 and more than 5 percent per year since 2001. Growth and development in developing countries is dependent on Agricultural development (World Bank, 2008). In Ghana, government agricultural development objective hinges on a demand-driven national agricultural strategy whose goals are development oriented, productivity enhancing, and competitiveness (Asuming-Brempong et al 1991).

In order to enhance productivity, technical efficiency measurements are crucial. Squires and Tabor (1990) defined technical efficiency as a farmer's ability to produce the maximum output possible from a given set of inputs and production technology. This concept is relative since each farm's production performance is compared to a best-practice input-output relationship or frontier. The best-practices production frontier is established by the practices of the most efficient farmers. Thus, the deviation of the individual farm from the frontier measures technical efficiency (TE). From an aggregate and time series perspective, the best-practice frontier is the potential output for the best practice year. Thus, the TE in that case, is the gap between the actual output for any particular year and the potential output of the best practice year. 


\section{Literature Review}

\subsection{Measurement Issues}

TE and the question of how to measure it, is an important subject in developing countries' agriculture (Ashok et al, 1995; Hazarika and Subramanian, 1999). There are four major approaches to measure efficiency (Coelli et al., 1998). These are the non-parametric programming approach (Charnes et al., 1978), the parametric programming approach (Aigner and Chu, 1968; Ali and Chaudry, 1990), the deterministic statistical approach (Afriat, 1972; Schippers, 2000; Fleming et al., 2004) and the stochastic frontier approach. The last is preferred for assessing efficiency in agriculture because of the inherent stochasticity involved (Coelli, 1995; Ezeh, 2004). Among these, the stochastic frontier and non-parametric programming, known as Data Envelopment Analysis (DEA), are the most popular approaches.

The foundation of Stochastic Frontier Analysis (SFA) was laid independently of each other in papers by Aigner et al. (1977) and by Meeusen and van den Broeck (1977). In the last couple of decades, there has been a surge with extensions to estimate technical change, efficiency change, and productivity change measures using stochastic frontier analysis (e.g., Kumbhakar and Lovell, 2000; Greene, 2004). Other dimensions included distribution of the asymmetric component, $u$ (inefficiency) and conditional estimation of inefficiency. In terms of data type, the original works relied on cross-sectional data, however, others (Miljkovic and Shaik, 2010) have employed time series, whilst yet others have used panel data to estimate fixed effects, random effects, and time variant inefficiencies. The development of SFA went hand-in-hand with advances in econometrics such as Bayesian estimation method for panel data, estimations based on simulation techniques among others. In a myriad of cross-sectional studies, (see e.g. Alabi \& Osifo, 2005; Amos, 2007), and rarely in the case of time series work (Miljkovic and Shaik, 2010), determinants of the estimated technical efficiencies were investigated.

\subsection{Empirical Evidence}

Nkamleu et al, (2006) examined 27 countries covering five sub-regions of Africa, over the period 1971-2000, and established TE for African countries relative to the meta-frontier, between $57 \%$ and $94 \%$. Central African countries led with 94\% with Southern African scoring the least. Western African countries measured $72 \%$ relative the African Frontier whilst a measure of $92 \%$ was recorded for individual countries relative to the sub-regional frontier. The three ten-year mean TE were relatively stable, 1971-1980, 75\%; 1981-1990, 73\% and 1991-2000 was $76 \%$. The continental average compares with the results of Thiam et al (2001), based on a meta-analysis of developing countries that, overall average TE for developing countries, was $68 \%$.

Oniell and Matthews (2001) studied technical efficiency (TE) of Irish agriculture using an unbalanced panel of 2,603 farms drawn from the Irish National Farm Survey over the period 1984 to 1998. An average technical efficiency level of between 65 and 70 per cent with a slight upward trend over the period was noted. Technical progress was observed at an unweighted rate of approximately 90 per cent and a weighted rate of 2.1 per cent per annum over 1984-98. Guyomard et al (2006) reported TE estimates for French Agriculture. Indexing 1995 measure to 100, they noted a decline of TE to 78.36 by 2002. Čechura (2010) estimated TE for Agricultural firms in Czech Republic at 90\%, for Agricultural companies in the Eastern European Country. O'Donnell (2002) provided evidence that, using a Bayesian methodology, U.S. Agricultural technical efficiency was $64 \%$ with variation among states. Concerning the Mediterranean region, Hassine \& Kandill, (2009) obtained a fairly reasonable estimate for input use. Specifically, all inputs elasticities for south and north Mediterranean countries were positive and significant at $10 \%$ level or better. In Asia, Li \& Wahl (2004) examined technical efficiency in Chinese Agriculture. TE estimated ranged from a high of 0.91 to a low of 0.71 . Labour (-0.111) and land (-0.018) were negatively related to Agricultural output measured as total value added. Power and fertiliser were positively related to output. Indeed, only, fertiliser was elastic, with a coefficient of 3.221. The results of Sotnikov (1998) were similar; average TE for 0.77 to 0.92 was obtained for 75 Russian regions over the period 1991-1993 with a slight decline to 0.78 by 1995 . These results were consistent with those of Bouzaher et al (1994) and Kurkalova and Jensen (1996) for Ukraine. Using ten states in Brazil, Igliori (2005) reported a mean TE of 38\% for Brazilian Agriculture, with a wide minimum and maximum of $1.3 \%$ and $92.3 \%$ respectively. The Brazilian mean TE is lower than the $73.8 \%$ reported for Nigeria, based on a meta-analysis of sixty-four studies covering 1999-2008 (Kolawole, 2009).

\section{Problem Statement}

Empirical studies have been reported for TEs for subsectors within Agriculture across countries. Moreira and Bravo-Ureta (2010) studied cross-country TEs for dairy farms in Argentina, Chile, and Uruguay. TEs estimated were $72.8,65.8$, and $73.4 \%$ for Argentina, Chile, and Uruguay, respectively. The average TEs for Argentina and Uruguay were not significantly different from each other but were significantly higher than the value for Chile. 
The production frontiers for Argentina and Uruguay were relatively close to the meta-frontier (MF), which suggested that these two countries might need little work to increase investments to promote local research to generate new technologies and/or search for technologies to adapt from areas that were more distant. Binam et al, (2008) estimated TE between $39 \%$ and $71 \%$ with mean $52 \%$ with respect to the meta-frontier in respect of cocoa for Cameroon, Ghana, Nigeria and Cote d'Ivoire. The TE of individual farms with respect to national frontiers was $4 \%$ for Ghana, $58 \%$ for Cote d'Ivoire, $65 \%$ for Cameroon and $74 \%$ for Nigeria. Onumah et al (2010) reported mean technical efficiency of fish farms in Ghana at 84\%. For rice farming, Al-Hasan (2008) found TE for irrigated rice farms to be $51 \%$ and non-irrigators to be $53 \%$. The test of the two showed no statistically significant difference. A significantly lower measure of $34 \%$ was reported for rice farmers in Upper East Region (Seidu et al, 2006). A higher mean TE of $74.8 \%$ was estimated for vegetable farmers (Peprah, 2010). Beyond the individual subsector and crops, and over time, what is the technical efficiency of Ghana's Agricultural sector?

\section{Objectives}

Response to the questions posed in section 3 will be provided by,

- describing the summary statistics of variables used in the estimation of the production function,

- estimating technical efficiency of Ghana's Agriculture.

\section{Significance}

Product level and subsector studies abound, but country level time series studies on technical efficiency are rear and that for Ghana covering fifty years period is non-existent. The current paper seeks to fill this void. Indeed, it may be the first major empirical analysis applying SFA technique to time series national data of Ghana. Farm resources such as pesticides, herbicides, and seeds are included in the production equation in addition to those used by Nkamleu et al, (2006). The level of technical efficiency of Agriculture in Ghana will be useful in policy planning, monitoring and evaluation.

\section{Organisation of study}

The rest of the paper is composed into four sections. Methodology is in section 7. Section 8 presents the results and accompanying discussions. The conclusions and associated recommendations constitute section 9. Some directions for further research are contained in section 10.

\section{Methodology}

\subsection{Model}

The work done by the pioneers, as noted earlier, specified the basic model as:

$$
y=f(X) e^{v-u}
$$

Following Miljkovic and Shaik (2010) and applying natural logarithm and matrix notation will result in stochastic production frontier model (2).

$$
\ln y_{t}=X_{t} \beta+v_{t}-u_{t}
$$

where $y_{t}$ denotes the output for the year $t(t=1, \ldots, N), \boldsymbol{X}_{t}$ is a vector of the production inputs as well as a column of ones, $\boldsymbol{\beta}$ is a vector of parameters to be estimated, $v_{t}$ and $u_{t}$ are error terms defined below. The frontier production function is a measure of the maximum potential output obtainable. Both $v_{t}$ and $u_{t}$ cause actual production to deviate from this frontier. The random variable in the production that cannot be influenced by producers is represented by $v_{t}$, is identically and independently distributed (iid) as $N\left(0, \sigma_{v}^{2}\right)$. The non-negative error term $u_{t}$ represents deviation from the maximum potential output attributable to technical inefficiency, which is independent of $v_{t}$. It is also assumed to be identically and independently truncated in $t$ instead of zero (half-normal distribution when $\mu=0)$ as $N\left(\mu, \sigma_{\mathrm{u}}^{2}\right)$. In other words: $\mathrm{E}\left[v_{t}\right]=0$ for all $t, \mathrm{E}\left[v_{t} v_{j}\right]=0$ for all $t$ and $j$ $(t \neq j), \mathrm{E}\left[v_{t}^{2}\right]=\sigma_{v}^{2}, \mathrm{E}\left[u_{t}\right]>0, \mathrm{E}\left[u_{t} u_{j}\right]=0$ for all $t$ and $j(t \neq j)$, and $\mathrm{E}\left[u_{t}^{2}\right]=\sigma_{u}^{2}$. The stochastic terms $v_{t}$ and $u_{t}$ are assumed to be uncorrelated.

Modifying Jondrow et al (1982), and following Miljkovic and Shaik (2010) the technical efficiency of agricultural production is given by the mean of the conditional distribution of $u_{t}$ given ${ }_{\mathrm{t}}$ as defined by:

$$
E\left(u_{t} / \varepsilon_{t}\right)=\frac{\sigma_{u} \sigma_{v}}{\sigma^{2}}\left[\frac{f\left(\varepsilon_{t} \lambda / \sigma\right)}{1-F\left(\varepsilon_{t} \lambda / \sigma\right.}-\frac{\varepsilon_{t} \lambda}{\sigma}\right]
$$


where $\lambda=\sigma_{u} / \sigma_{v}, \sigma^{2}=\sigma_{u}^{2}+\sigma_{v}^{2}$, while $f$ and $F$ represent the standard normal density and cumulative distribution functions respectively evaluated at $\varepsilon_{t} \lambda / \sigma$. The year specific technical efficiency is defined in terms of observed output $y_{t}$ to the corresponding $y^{*}$ using the available technology derived from the result of (3) as:

$$
T E_{t}=\frac{E\left(y_{t} \mid u_{t}, X_{t}\right)}{E\left(y_{t} \mid u_{t}=0, X_{t}\right)}
$$

Or

$$
T E_{t}=\frac{y_{t}}{y_{t}^{*}}=\frac{e^{\left(X_{t} \beta+v_{t}-u_{t}\right)}}{e^{\left(X_{t} \beta+v_{t}\right)}}=e^{-u_{t}}
$$

where $y_{t}$ is the observed output in year $t$ and $\mathrm{y}_{\mathrm{t}}{ }^{*}$ is the frontier output in year $t$.

The solution of equation 4 becomes $e^{-u_{t}}$ so that ${ }^{0 \leq \frac{y_{t}}{y_{t}} \leq 1}$. The above transformation constrains the technical efficiency of each year to a value between zero and one, and is inversely related to the inefficiency.

The measure of technical efficiency is thus based on the conditional expectation of (4), given the value of $\left(\mathrm{v}_{t}-\mathrm{u}_{t}\right)$ evaluated at the maximum likelihood estimates of the parameters $\boldsymbol{\beta}$ where the maximum value of $y_{t}$ is conditioned on $u_{t}=0$ (Battese and Coelli, 1995).

Upon the recommendation of Desai (1976), the practice of Li \&Wahl (2004), and Miljkovic and Shaik (2010), and due to empirical popularity and flexibility, a Cobb-Douglas production function (6) was estimated.

$$
\ln y_{t}=\beta_{0}+\sum_{j=1}^{6} \beta_{j} X_{j t}+v_{t}+u_{t}
$$

Where, $y_{t}$ represents total output per annum in constant 1999-2000 US dollars. $j$ is the number of explanatory variables, so that $j=(1,2 \ldots 6)$, such that $x_{1}$ is agricultural land in hectares, $x_{2}$ is labour in number of persons, $x_{3}$ is fertiliser consumption in tonnes, $x_{4}$ is tractor and combines in numbers, $x_{5}$ is other agrochemicals in US dollars and $x_{6}$ is seeds in tonnes. $v_{t}$ and $u_{t}$ are as defined earlier. Details of the data sources, augmentations, and descriptions follow.

\subsection{Data}

The analysis is based on data drawn from FAOSTAT (http://faostat.fao.org) system of statistics used for dissemination of statistics compiled by the Food and Agricultural Organisation. Data on Agriculture in Ghana, 1961 to 2010 was used. Data consisted of information on agricultural production and means of production in the Ghana. Record of agricultural production, land under agricultural production, agricultural labour, number of tractors and combines in use, quantity of fertiliser used, quantity of other agrochemicals, and seeds were obtained. Below are the specifications of output and input variables:

\subsubsection{Output}

Agricultural production: Output in 1991-2000 prices Standard Local Currency (Ghana Cedis) was obtained. The data was converted to US dollar by multiplying the inverse of the exchange rate (GHC/US\$) data obtained from International Financial Statistics (IFS) of the IMF with output in Ghana cedis. This resulted in US dollar value for production. It is worth noting, that, in 2007, Ghana redenominated its currency. In order to conform the 2007-2010 data in GHS/US\$ to that of 1961 to 2006 in GHC/US\$, the GHS/US\$ values were multiplied by 10 000 .

\subsubsection{Inputs}

- Agricultural land: The sum of area under arable land (land under temporary crops, temporary meadows for mowing or pasture, land under market and kitchen gardens and land temporarily fallow), Permanent crops (land cultivated with crops that occupy the land for long periods and need not be replanted after each harvest, such as cocoa, coffee and rubber), and Permanent pastures (land used permanently for herbaceous forage crops, either cultivated or growing wild).

- Labour: This refers to economically active population in agriculture for each year, in Ghana. Economically active population in agriculture was defined as all persons engaged or seeking employment in agriculture, 
forestry, hunting or fishing sector, whether as employers, own-account workers, salaried employees or unpaid workers. Estimates and projection data was available from 1980 to 2050 . The 19 years missing data was filled by computing the average annual growth rate for the 1980-2050 period and using the average annual growth rate to compute the data points for 1961 to 1979 . The economically active population in agriculture, which is the best proxy of labour input into the agricultural sector was not used, since it was not possible to have information on differentials in skill levels and the number of hours worked on the farm. The population is numbers of persons.

- Fertiliser: Fertilisers used in Ghana involved different amounts and different types. According to studies (Hayami and Ruttan, 1970; Rao et al., 2003), the sum of nitrogen $(\mathrm{N})$, potassium $\left(\mathrm{P}_{2} \mathrm{O}_{5}\right)$ and phosphate $\left(\mathrm{K}_{2} \mathrm{O}\right)$ expressed in thousands of tonnes, that is contained in the commercial fertilisers consumed should be used as measure of fertiliser input. However, data of this measure was available only for 2002 to 2008. As a result, total consumption of all fertilisers was used. Fertiliser was measured in tonnes.

- Tractors and Combines: This variable excludes hoes, cutlasses and bullock ploughs which are important machinery for farming in Ghana. However, in the absence of such secondary data on hoe, cutlass and bullock ploughs; number of tractors, which refer to total wheel and crawler tractors (excluding garden tractors) used for agricultural production and combine harvesters, were employed to represent machinery capital. Tractors and combines were measured in numbers.

- Agrochemicals: Despite the assertion of Mundlak et al (2002) that fertiliser consumption is often viewed as a proxy for the whole range of chemical inputs and more, availability of data on agrochemicals specifically pesticides, herbicides and so on used in agricultural production were included as additional inputs. This was computed as import plus production minus exports equals consumption. This computation was necessitated because query of FAOSTAT for consumption for Ghana yielded null set elements. Agrochemicals were measured in US dollars.

- Seed: Planting materials measured in tonnes.

\section{Results and Discussion}

The results of the analysis are presented and discussed in three parts; the summary statistics, properties of the production function and the technical efficiency estimates.

\subsection{Summary Statistics}

The mean value of agricultural value added is US\$2 269m constituting about half of the maximum output of US\$5 890m (Table 1). The fifty-year average (1961-2010) of agricultural labour force is $3.49 \mathrm{~m}$. This is about half of the maximum of $6.0 \mathrm{~m}$ in 2010 and about twice of the figure for 1961 of $1.6 \mathrm{~m}$ persons. On average, about 2000 tractor and combines have been used annually. In respect of agrochemicals other than fertiliser (pesticides and herbicides), the average annual utilisation is valued at US\$49m, representing about $2 \%$ of the average value added of agricultural production. The mean fertiliser consumption of 23066 tonnes is only $12 \%$ of the African average of 179472 tonnes (ADI). This is quite low indicating the possibility of low usage of fertilisers

\subsection{Estimation Results}

In table 2, the results of the estimation is presented. All the coefficients are significant at $1 \%$ except for seed. Land cultivated, though significant does not have the appropriate sign; that is, it is negative. This is similar to Li $\&$ Wahl (2004) who obtained a negative sign for land in Chinese Agriculture. The negative sign suggest over use of land. Thus, a decrease in land use will stimulate output ceteris paribus. With the growing population, that brings along with it demand for alternative land uses, this results suggests efforts at maximising land use is required. Seed consumption is negatively related to output. The natural logarithm model estimation implies that the coefficients are elasticities. A $1 \%$ increase in labour will lead to $1.28 \%$ increase in output. This is contrary to Li \& Wahl (2004) who established a negative and inelastic relationship for Chinese Agriculture. The positive and elastic sign conforms to expectation, as agriculture in Ghana is labour intensive (Table 2). This is the highest elasticity among all the coefficients, and suggests the importance of labour in Ghana's agriculture. A $1 \%$ increase in fertiliser consumption will lead to $0.66 \%$ increase in output. This varies with findings for China, where fertiliser is elastic with coefficient of 3.221 . Output of agriculture will respond by $0.14 \%$ to a $1 \%$ increase in tractor and combine harvester usage. Li \& Wahl (2004) documents a lower coefficient for China (0.067) which is nonetheless inelastic to Agriculture value added. A 1\% increase in pesticide and herbicide usage will induce $0.23 \%$ increase in agricultural output. The positive relations with output indicate the need for these materials to be available for use. The highest inelastic figure of 0.66 for fertiliser is not surprising, as fertilisers tends to be more affordable and adopted than other agrochemicals and tractors and combines. The current low use of machinery may account for the inelastic response of tractor and combines to output. The usage of these inelastic 
capital items increases with agricultural transformation. The implication is that, the dominant technology in Ghana's Agriculture is less capital-intensive and more labour intensive. Transformation to more capital-intensive operations will increase productivity due to land. Additionally, with increasing population, land for non-agricultural uses will increase. Efforts at land productivity measures such as use of other inputs will be appropriate. The sum of the elasticities of the explanatory variables indicates the returns to scale of the production. From table 2, the sum of the elasticities is 1.74 , which is indicative of increasing returns-to-scale. Thus, $1 \%$ increase in all inputs will result in more than $1 \%(1.74 \%)$ increase in output. Increasing input utilisation together will pay-off. The individual elasticities should guide changes in input use.

\subsection{Estimates of TE}

Summary statistics of technical efficiency estimates (computed from table 3) are presented in table 4. The mean of the TE is 0.82 , recorded in 1985 and 1992. The median is 0.85 recorded in 1969,1990 , and 2006. The mean compares favourably with those of Oniell and Matthews (2001) and Guyomard et al (2006). The mean of $82 \%$ is higher than 38\% for Brazil (Igliori, 2005) and 78\% for Nigeria (Kolawole, 2009), 53\% and 59\% respectively for non-irrigated and for irrigated rice in Northern Ghana (Al-Hasan, 2008). The average TE compares with $85 \%$ estimated for fish farms in Ghana (Onumah et al, 2010). In respect of the dispersion of the TEs, the minimum is 0.59 (2001) and a maximum is 0.96 (1978). The high of $96 \%$ shows that highest yearly technical efficiency of Agriculture was only 4\% below the frontier. The minimum of $59 \%$ indicates that inefficiency in any year between 1961 and 2010 was less than 50\%. This is quite encouraging. The high of $96 \%$ exceeded China's $92 \%$ high (Li and Wahl, 2004), however, China's low of 71\% exceeded Ghana's minimum of 59\%. The TEs possess a range of 0.37 indicating the difference between the lowest and the highest TE. This is lower than the minimum and slightly above the half of the minimum and less than half the mean. The more reliable measure of spread is the standard deviation. The TEs possess a statistic of 0.10 . Thus a spread of one standard deviation from the mean equals 0.92 , covering $39(79 \%)$ of the TEs. This is higher than the required $68 \%$ for normal distributions suggesting an extremely narrow spread of the TE measures. The narrow spread around the mean of $82 \%$ points to a strong technical efficiency of Ghana's Agriculture over the study period.

\section{Conclusions and Recommendations}

\subsection{Conclusion}

Key resources respond positively to agricultural output in Ghana. Labour is output elastic. Other inputs are inelastic. The returns-to-scale is 1.74 thus an increasing one. Technical efficiency estimated for Ghana's agriculture using time series data over a fifty-year period (1961 to 2010) was greater than 50\%. The maximum technical efficiency obtained was $96 \%$ and a minimum of $59 \%$ with a mean of $82 \%$. This suggests that Ghana's agriculture, which uses labour intensive technology and largely smallholder, is quite efficient. However, work needs to be done to make up for the average of $18 \%$ inefficiency.

\subsection{Recommendation}

With more than 50\% of the labour force in Ghana engaged in Agriculture, coupled with the inelastic response of output to technology enhancing agricultural inputs, there is evidence that Ghanaian Agriculture requires transformation into capital-intensive production technology. Land productivity measures such as modernisation of agriculture by use of other inputs are required to reduce land use, as Ghana's Agriculture exhibits an increasing returns-to-scale.

\section{Direction for Further Research}

The significance of the constant term may indicate omission of some important variables. In the light of this, rainfall, cutlass, and hoes (farm tools) the use of which dominate production than tractor and combines, may be considered for inclusion. Having estimated technical efficiency, it will be appropriate to investigate the determinants of the TE in Ghana's Agriculture at the national level.

\section{References}

Afriat S.N. (1972). Efficiency Estimation of the Production Function. International Economic Review, 13, 568-598. http://dx.doi.org/10.2307/2525845

Aigner D.J., Chu S.F. (1968). Estimating the Industry Production Function. American Economic Review, 58, 826-839.

Aigner D., Lovell C.A.K., Schmidt P. (1977). Formulation and Estimation of Stochastic Frontier Production Function Models. Journal of Econometrics, 6, 21-37. http://dx.doi.org/10.1016/0304-4076(77)90052-5

Al-hassan S. (2008). Technical Efficiency of Rice Farmers in Northern Ghana AERC Research Paper 178, 
African Economic Research Consortium, Nairobi, April.

Alabi, R.A., \& Osifo, A.A. (2005). Population Density and Technical Efficiency of Cocoa Based Agroforestry. Bowen Journal of Agriculture, 2(2), 216-224.

Ali, M. \& Chaudry, M.A. (1990). Inter-regional Farm Efficiency in Pakistan's Punjab: A Frontier Production $\begin{array}{lllll}\text { Function Study. Journal of Agricultural Economics, } & 41,\end{array}$ http://dx.doi.org/10.1111/j.1477-9552.1990.tb00619.x

Amos, T.T. (2007). An Analysis of Productivity and Technical Efficiency of Smallholder Cocoa Farmers in Nigeria. Journal of Social Sciences, 15(2), 127-133.

Ashok, P., Ali, F. \& Shah, M.M.K. (1995). Measurement of Economics Efficiency in Pakistani Agriculture. American Journal of Agriculture, 77, 675-685. http://dx.doi.org/10.2307/1243234

Asuming-Brempong, S. (1991). Agricultural Marketing Development in Ghana Technical Report for MOFA/World Bank, Accra Ghana.

Binam, J.N., Gockowski, J., \& Nkamleu, G.B. (2008). Technical Efficiency and Productivity Potential of Cocoa Farmers in West African Countries: A Meta Frontier Approach. The Developing Economies, 46 (3), 242-263. http://dx.doi.org/10.1111/j.1746-1049.2008.00065.x

Bogetic, Y., Bussolo, M., Ye, X., Medvedev, D., Wodon, Q. \& Boakye, D. (2007). Ghana's Growth Story: How to Accelerate Growth and Achieve MDGs. Background paper for Ghana CEM, April.

Bouzaher, A., Carriquiry, A. \& Jensen, H. (1994). The Structure of Ukranian Agriculture: Comparative Efficiency and Implications for Policy Reform. Working Paper 94-SR 72. Ames: Centre for Agricultural and Rural Development. Iowa State University.

Čechura, L. (2010). Estimation of Technical Efficiency in Czech Agriculture with Respect to Firm Heterogeneity. Agricultural Economics - Czech, 56 (4), 183-191.

Charnes, A., Copper, W. \& Rhodes E. (1978). Measuring the Efficiency of Decision-Making Units. European Journal of Operations Research, 2, 429-444. http://dx.doi.org/10.1016/0377-2217(78)90138-8

Coelli T.J. (1995). Estimators and Hypothesis Tests for a Stochastic Frontier Function: A Monte Carlo Analysis. Journal of Productivity Analysis, 6(4), 247-268. http://dx.doi.org/10.1007/BF01076978

Coelli T.J, Prasada R, \& Battese G.E. (1998). An Introduction to Efficiency and Productivity Analysis. Kluwer Academic Publishers. Boston. http://dx.doi.org/10.1007/978-1-4615-5493-6

Coulombe, H., \& Q. Wodon. (2007). Combining Census and Household Survey Data for Better Targeting: The West and Central Africa Poverty Mapping Initiative, Findings No. 280, Africa, Region, the World Bank, Washington, D.C.

Desai, P. (1976). The Production Function and Technical Change in Postwar Soviet Industry: A Reexamination. The American Economic Review, 66 (3), 372-381. Available at: http://www.jstor.org/stable/1828170.

Ezeh C.I. (2004). A Comparative Study of Fadama and Non-Fadama Crop Farmers in Osisioma-Ngwa L.G.A, Abia State. Nigeria. Journal of Sustainable Tropical Agricultural Research, 11.

Fleming, E., Fleming, P., Rodgers, H., Grifften, G. \& Johnston, D. (2004). Animal Efficiency in an Intensive Beef Production. Genetic Breeding Unit, University of New England, Armidale, NSW, Australia.

Greene W.H. (2004). Fixed and Random Effects in Stochastic Frontier Models. Journal of Productivity Analysis, 23(1), 7-32. http://dx.doi.org/10.1007/s11123-004-8545-1

Guyomard, H., Latruffe, L., \& Le Mouël, C. (2006). Technical Efficiency, Technical Progress and Productivity Change in French Agriculture: Do Subsidies and Farms' Size Matter? $96^{\text {th }}$ EAAE Seminar, 10-11 January 2006, Tänikon, Switzerland.

Hassine, N.B. \& Kandill, M. (2009). Trade Liberalisation, Agricultural Productivity and Poverty in the Mediterranean Region. European Review of Agricultural Economics, 36 (1), 1-29. http://dx.doi.org/10.1093/erae/jbp002

Hayami, Y. \& Ruttan, V.W. (1970). Agricultural productivity differences among Countries. American Economic Review, 60, 895-911.

Hazarika, C. \& Subramanian, S.R. (1999). Estimation of Technical Efficiency in the Stochastic Frontier Production Function Model: An Application to the Tea Industry in ASAM. Indian Journal of Agricultural 
Economics, 54(2), 201-211.

Igliori, D. C. (2005). Determinants of Technical Efficiency in Agriculture and Cattle Ranching: A Spatial Analysis for the Brazilian Amazon Working Paper No. 09. University of Cambridge Land Economy. Accessed from http://ssrn.com/abstract=753499 on $2^{\text {nd }}$ May 2011 at 14:30 GMT.

ISSER. (2007). The State of the Ghanaian Economy. Institute of Statistical, Social and Economic Research Legon, Accra.

Jondrow, J., Lovell, C. A. K. Materov, I. S. \& P. Schmidt. (1982). On Estimation of Technical Inefficiency in the Stochastic Frontier Production Function Model. Journal of Econometrics, 19, 233-38. http://dx.doi.org/10.1016/0304-4076(82)90004-5

Kolawole, O. (2009). A Meta-analysis of Technical Efficiency in Nigerian Agriculture. Contributed Paper prepared for presentation at the International Association of Agricultural Economists Conference, Beijing, China, August 16-22, 2009.

Kumbhakar, S. C., \& Lovell, C. A. K. (2000). Stochastic Frontier Analysis. New York, NY: Cambridge University Press.

Kurkalova, L. \& Jensen, H. (1996). Production Efficiency in Ukranian Agriculture and the Process of Economic Reform. Working Paper 96-WP 167. Centre for Agricultural and Rural Development, Iowa State University.

Li, Q. \& Wahl, T.I. (2004). Efficiency and Technological Progress in the Chinese Agriculture: the Role of Foreign Direct Investment. Selected paper presented at the American Agricultural Economics Association Annual Meetings, Denver, CO-August 1-4, 2004.

Meeusen W., \& van den Broeck, J. (1977). Efficiency Estimation from Cobb-Douglas Production Functions with Composed Error. International Economic Review, 18, 435-444. http://dx.doi.org/10.2307/2525757

Miljkovic, D. \& Shaik, S. (2010). The Impact of Trade Openness on Technical Efficiency in U.S. Agriculture Agribusiness \& Applied Economics Report, No. 660, Department of Agribusiness and Applied Economics, Agricultural Experiment Station, North Dakota State University, Fargo, ND 58108-6050

Moreira, V. H. \& Bravo-Ureta, B. E. (2010). Technical Efficiency and Meta-Technology Ratios for Dairy Farms in Three Southern Cone Countries: A Stochastic Meta-Frontier Model. Journal of Production Analysis, 33, 33-45. http://dx.doi.org/10.1007/s11123-009-0144-8

Mundlak, Y. Larson, D. F. \& Butze, R. (2002). Determinants of Agricultural Growth in Thailand, Indonesia, and The Philippines. Discussion Paper, No. 302. Center, for Agricultural Economic Research, The Hebrew University of Jerusalem.

Nkamleu, G.B., Nyameck, J., \& Sanogo, D. (2006). Metafrontier Analysis of Technology Gap and Productivity Difference in African Agriculture Journal of Agriculture and Food Economics, 1(2), 111-120.

O' Donnell C.J. (2002). Parametric Estimation of Technical and Allocative Efficiency in US Agriculture In V. Eldon Ball, E.V., Norton, G.W., (Eds) Agricultural Productivity: Measurement and Sources of Growth, (pp. 137-166) Springer, Business and Economics.

O'neill, S. \& Matthews, A. (2001). Technical Change and Efficiency in Irish Agriculture. The Economic and Social Review, 32 (3), 263-284.

Onumah, E. E., Brümmer, B., \& Hörstgen-Schwark, G. (2010). Elements Which Delimitate Technical Efficiency of Fish Farms in Ghana Journal of the World Aquaculture Society, 41(4), 506-518.

Peprah, J. A. (2010). Access to Credit and Technical Efficiency of Vegetable Growers in Mfantsiman District of Ghana. Available at SSRN: http://ssrn.com/abstract=1805218 and downloaded on $2^{\text {nd }}$ May, 2011 at 21:00 GMT.

Rao, D.S.P., O’Donnell, J. \& Battese, G.E. (2003). Metafrontier Functions for the Study of Inter-Regional Productivity Differences. Centre for Efficiency and Productivity Analysis Working Paper 1.

Schippers, R.R. (2000). African Indigenous Vegetables, an Overview of the Cultivated Species, Chathan UK: Natural Resources Institute/ACP-EU Technical Centre for Agriculture and Rural Cooperation.

Seidu, A., Sarpong, D.B., \& Asuming-Brempong, S. (2006). Smallholder Rice Farms In Ghana: An Analysis of Technical Efficiency Based on Different Farming Systems And Gender The IUP Journal of Agricultural Economics, 1 (3), 21-33.

Sotnikov, S. (1998). Evaluating the Effects of Price and Trade Liberalisation on the Technical Efficiency of Agricultural Production in a Transition Economy: The Case of Russia. European Review of Agricultural 
Economics, 25, 412-431.

Squires D. \& Tabor, S. (1990). Technical Efficiency and Future Production Gains In Indonesian Agriculture The Developing Economies XXIX 3 September.

Thiam, A., Bravo-Ureta, B.E., \& Rivas, T.E. (2001). Technical Efficiency in Developing Country Agriculture: A Meta-Analysis. Agricultural Economics, 25, 235-243. http://dx.doi.org/10.1111/j.1574-0862.2001.tb00204.x

World Bank. (2008). World Development Report 2008. Agriculture for Development. World Bank. 1818 H. Street N. W. Washington D.C. 20433.

\section{Appendices}

Table 1. Summary Statistics of Variables

\begin{tabular}{|l|r|r|r|r|}
\hline \multicolumn{1}{|c|}{ Variables } & \multicolumn{1}{c|}{ Mean } & \multicolumn{1}{c|}{ St. Deviation } & \multicolumn{1}{c|}{ Min } & \multicolumn{1}{c|}{ Max } \\
\hline Value Added Agric. (US\$) & 2269793109.97 & 1292847015.13 & 460597236.77 & 5890369711.18 \\
\hline Land (Ha) & 12902490.63 & 1358606.77 & 11700000.00 & 15797227.60 \\
\hline Economically Active (s) & 3490878.26 & 1305045.93 & 1672166.08 & 6058000.00 \\
\hline Tractors \& Combines (numbers) & 2010.60 & 199.55 & 1010.00 & 2249.00 \\
\hline Fertilizer (tonnes) & 23066.00 & 32331.63 & 718.00 & 181990.00 \\
\hline Agrochemicals (US\$) & 49057893.51 & 9636950.79 & 1016000.00 & 474503732.15 \\
\hline Seeds (tonnes) & 100865.46 & 46186.63 & 31757.00 & 199859.89 \\
\hline
\end{tabular}

SOURCE: Computed from secondary data collected. Table shows the summary statistics of variables employed in the estimations.

Table 2. Estimates of Stochastic Production Function

Dependent Variable: Value Added Agriculture (US) in natural logarithm

\begin{tabular}{|c|c|c|c|c|}
\hline Variables (All in natural logs) & Parameters & ML Function & St. Error & t-ratio \\
\hline Constant & $\beta_{0}$ & 53.16 & 12.89 & $4.12 * * *$ \\
\hline Agricultural land in (hectares) $\left(X_{1}\right)$ & $\beta_{1}$ & -0.36 & 0.87 & $-4.11 * * *$ \\
\hline Labour in (number of persons) $\left(X_{2}\right)$ & $\beta_{2}$ & 1.28 & 0.29 & $4.39 * * *$ \\
\hline Fertilizer consumption (tonnes) $\left(X_{3}\right)$ & $\beta_{3}$ & 0.66 & 0.20 & $3.23 * * *$ \\
\hline Tractor and combines (numbers) $\left(X_{4}\right)$ & $\beta_{4}$ & 0.14 & 3.57 & $3.87 * * *$ \\
\hline Other agrochemicals (US dollars) $\left(X_{5}\right)$ & $\beta_{5}$ & 0.23 & 5.42 & $4.33 * * *$ \\
\hline Seeds (tonnes) $\left(X_{6}\right)$ & $\beta_{6}$ & -0.21 & 0.19 & -1.23 \\
\hline \multicolumn{5}{|c|}{ Variance Parameters } \\
\hline Sigma squared & $\sigma^{2}$ & 0.0750 & 0.025 & 2.95 \\
\hline Gamma & $\gamma=\sigma^{2} u / 2$ & 0.876 & 0.139 & 6.30 \\
\hline Meu & $\mu$ & \multicolumn{3}{|c|}{ Restricted to zero } \\
\hline Eta & & \multicolumn{3}{|c|}{ Restricted to zero } \\
\hline Log likelihood function & & \multicolumn{3}{|c|}{15.74} \\
\hline LR test on one sided error & & \multicolumn{3}{|c|}{1.29} \\
\hline
\end{tabular}

SOURCE: Estimated results from FRONTIER 4.1. The table contains the results of the estimations from FRONTIER 4.1c using data outlined in 7.2.1 and 7.2.2. 
Table 3. Estimates of Technical Efficiency in Ghana's Agriculture

\begin{tabular}{|c|c|c|c|c|c|}
\hline Year & T E. & Year & T E. & Year & T E. \\
\hline 1961 & 0.92 & 1981 & 0.73 & 2001 & 0.59 \\
\hline 1962 & 0.83 & 1982 & 0.90 & 2002 & 0.62 \\
\hline 1963 & 0.70 & 1983 & 0.94 & 2003 & 0.71 \\
\hline 1964 & 0.70 & 1984 & 0.91 & 2004 & 0.81 \\
\hline 1965 & 0.93 & 1985 & 0.82 & 2005 & 0.81 \\
\hline 1966 & 0.93 & 1986 & 0.95 & 2006 & 0.85 \\
\hline 1967 & 0.66 & 1987 & 0.89 & 2007 & 0.91 \\
\hline 1968 & 0.67 & 1988 & 0.88 & 2008 & 0.94 \\
\hline 1969 & 0.85 & 1989 & 0.86 & 2009 & 0.93 \\
\hline 1970 & 0.86 & 1990 & 0.85 & 2010 & 0.92 \\
\hline 1971 & 0.87 & 1991 & 0.94 & & \\
\hline 1972 & 0.83 & 1992 & 0.82 & & \\
\hline 1973 & 0.86 & 1993 & 0.77 & & \\
\hline 1974 & 0.86 & 1994 & 0.72 & & \\
\hline 1975 & 0.72 & 1995 & 0.83 & & \\
\hline 1976 & 0.71 & 1996 & 0.73 & & \\
\hline 1977 & 0.78 & 1997 & 0.63 & & \\
\hline 1978 & 0.96 & 1998 & 0.86 & & \\
\hline 1979 & 0.88 & 1999 & 0.93 & & \\
\hline 1980 & 0.91 & 2000 & 0.64 & & \\
\hline
\end{tabular}

SOURCE: Estimated from FRONTIER 4.1 using data collected from data sources mentioned in 7.2.1 and 7.2.2. The table contains the estimated TEs for each of the study years.

Table 4. Summary Statistics of TE

\begin{tabular}{|l|c|}
\hline Central Tendency & \\
\hline Mean & 0.82 \\
\hline Median & 0.85 \\
\hline Dispersion & \\
\hline Max & 0.96 \\
\hline Min & 0.59 \\
\hline Range & 0.37 \\
\hline Standard Deviation & 0.10 \\
\hline 1 Std. dev. & $0.92(78 \%)$ \\
\hline
\end{tabular}

SOURCE: Calculated from TE estimates in table 3. 